The Geneva Papers on Risk and Insurance, 20 (No. 75, January 1995), 127-140

\title{
The life insurance industry in South Africa
}

\author{
by A. Reg Munro* and Anton M. Snyman**
}

\section{Introduction}

It is often acknowledged that South Africa has a sophisticated financial services industry in terms of products, services and distribution infrastructure. The highly developed life insurance industry makes a significant contribution to this sophistication. The assets of life insurance companies and pension funds correspond to well over $80 \%$ of GDP, a ratio that is higher than in the United States and Canada, though lower than in Switzerland, the Netherlands and the UK. More significantly, South Africa has the highest level of life insurance premiums in relation to GDP in the world, with total life premiums amounting to $10,3 \%$ of GDP (Sigma, March 1994).

The growth of the industry can be explained not only by the fiscal incentives that have supported the creation of funded company schemes as well as voluntary saving with insurance companies, but also by the achievement over long periods of high rates of return relative to those available on alternative fixed interest investments. Its impressive record of innovation has been an important factor. South African insurance companies claim to have invented universal life and annuity policies. More recently, insurance companies have innovated with policies linked to serious illnesses, so-called dread disease policies.

\section{Structure of the industry}

A feature of the life insurance industry in South Africa is its very high concentration and the dominance of the sector by two long standing but very efficient mutual organizations, Old Mutual and Sanlam. These have strong interests throughout the financial sector and maintain large holdings in numerous industrial and commercial companies. The two largest companies each account for some one-third of total premiums, giving a combined total of two-thirds of the market. Two private joint-stock companies, Liberty with some $10 \%$ and Southern with around $7,5 \%$ of the market, underscore the concentration of the industry as the four largest groups control some five-sixths of total premiums. The other 27 life companies share the remaining one-sixth.

* General Manager (Services), Old Mutual, Cape Town.

** Corporate Planner, Old Mutual, Cape Town. 
Competition is strong and premiums are adjusted on a frequent basis in response to changing market conditions on investment yields and competitive offerings.

\section{Contribution to South African economy}

In Southern Africa (i.e. South Africa, Namibia and Zimbabwe) life insurance companies have achieved remarkable success in capturing premium income representing a large share of the national GDP as is evidenced by the figures in Table I below.

\subsection{An international comparison (1992)}

\section{Table I}

\begin{tabular}{|c|c|c|}
\hline & Country & $\begin{array}{c}\text { Life Premiums as } \\
\% \text { GDP }\end{array}$ \\
\hline 1. & South Africa & 10.3 \\
\hline 2. & South Korea & 9.8 \\
\hline 3. & United Kingdom & 7.3 \\
\hline 4. & Japan & 6.3 \\
\hline 5. & Ireland & 5.2 \\
\hline 6. & Switzerland & 5.0 \\
\hline 7. & Netherlands & 4.5 \\
\hline 8. & Luxemborg & 4.4 \\
\hline 9. & Finland & 4.3 \\
\hline 10. & Australia & 3.9 \\
\hline 11. & France & 3.8 \\
\hline 12. & United States & 3.6 \\
\hline 13. & Taiwan & 3.3 \\
\hline 14. & Canada & 3.0 \\
\hline 15. & Zimbabwe & 2.9 \\
\hline
\end{tabular}

Source: Sigma, Economic Studies No. 3/94

For two developing countries, South Africa and Zimbabwe, to rank 1st and 15th in the world illustrates the performance achieved by the 32 and 6 insurance companies in these economies. Key to this performance is the active and successful role played by life assurers in the retirement provision industry ( See 3.3).

\subsection{Life assurers assets in South Africa}

As the result of collecting these premiums, the assets of life assurers in South Africa represent a growing percentage of GDP. 
Figure I

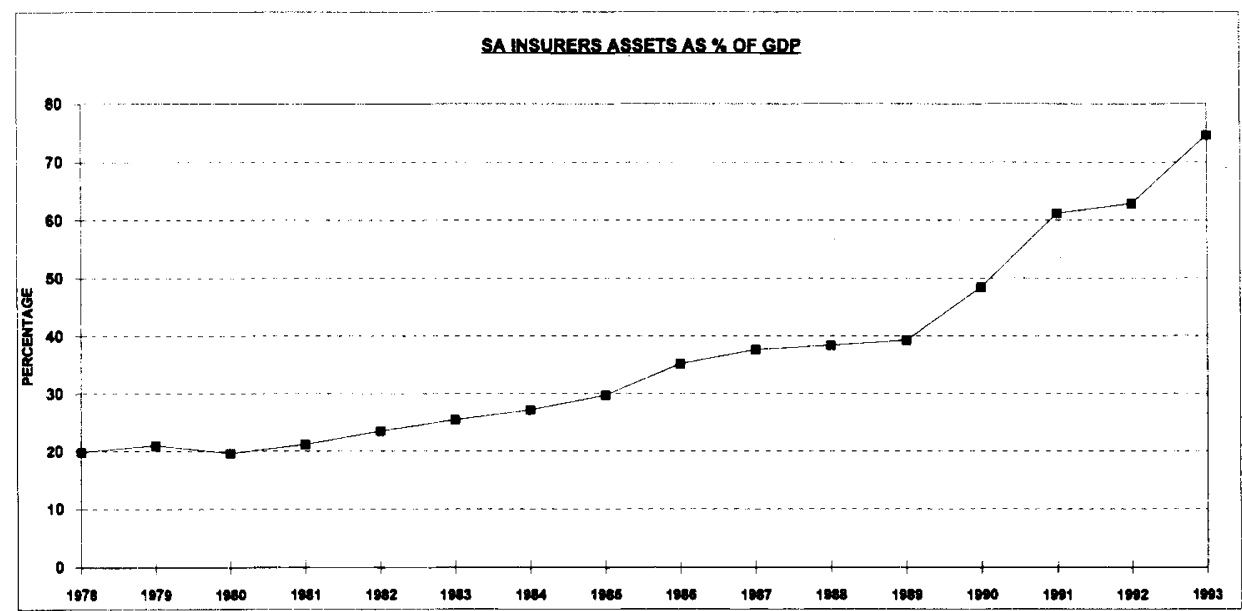

\subsection{Success in retirement funds}

One of the major differences between South Africa and the highly industrialised nations is the fact that social security provisions for old age provides only very minimal means tested benefits. In Southern Africa the private retirement fund provision industry has been successful in exploiting this lack and life insurers have played a significant role.

\section{Figure II}




The above graph shows the annual flow of contributions to retirement funds all expressed as a percentage of GDP.

Contributions made to all retirement funds i.e. including pension, provident and retirement annuity (personal pension) funds, have constituted a fairly constant $6 \%$ of GDP over much of the period under consideration. The significant kick up in 1991 is fully explaired by a one off increase of R2 billion i.e. $100 \%$ over 1990 in contributions to funds covering government employees.

The inflow to life insurers i.e. private pension policies and insured group retirement plans, over the period has increased from $2 \%$ to $3 \%$ of GDP over the period. Much of this growth has resulted from life insurers' ability to switch self-administered pension fund flows due to their ability to demonstrate the achievement of better investment returns achieved on retirement fund assets administered.

This success is further illustrated by Figure III which compares the assets of life insurers with those of retirement funds and Deposit Taking Institutions (DTI).

\section{Figure III}

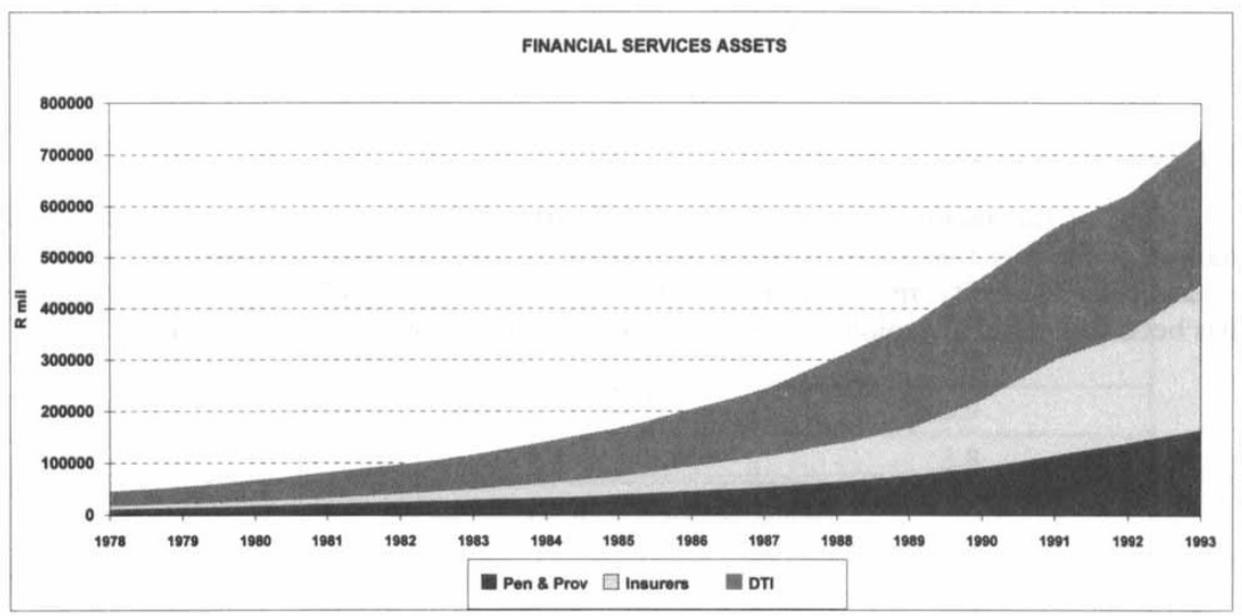

Over the period (1978-1993) the life insurer assets has increased at $27,4 \%$ per annum while the total assets involved have grown from $R 44,7$ bil to $R 745,5$ bil i.e. by $20,6 \%$ per annum. This has resulted in the life assurer share increasing from $17 \%$ to $38 \%$ over the period.

Figure IV shows that the above trends have resulted in life insurers assets growing from $20 \%$ to $75 \%$ of GDP while retirement fund assets grew more slowly from $28 \%$ to $42 \%$ of GDP.

\subsection{Individual policy business}

Individual policies are sold by some 30000 intermediaries including life office agents and brokers who sell for several companies. 
Figure IV

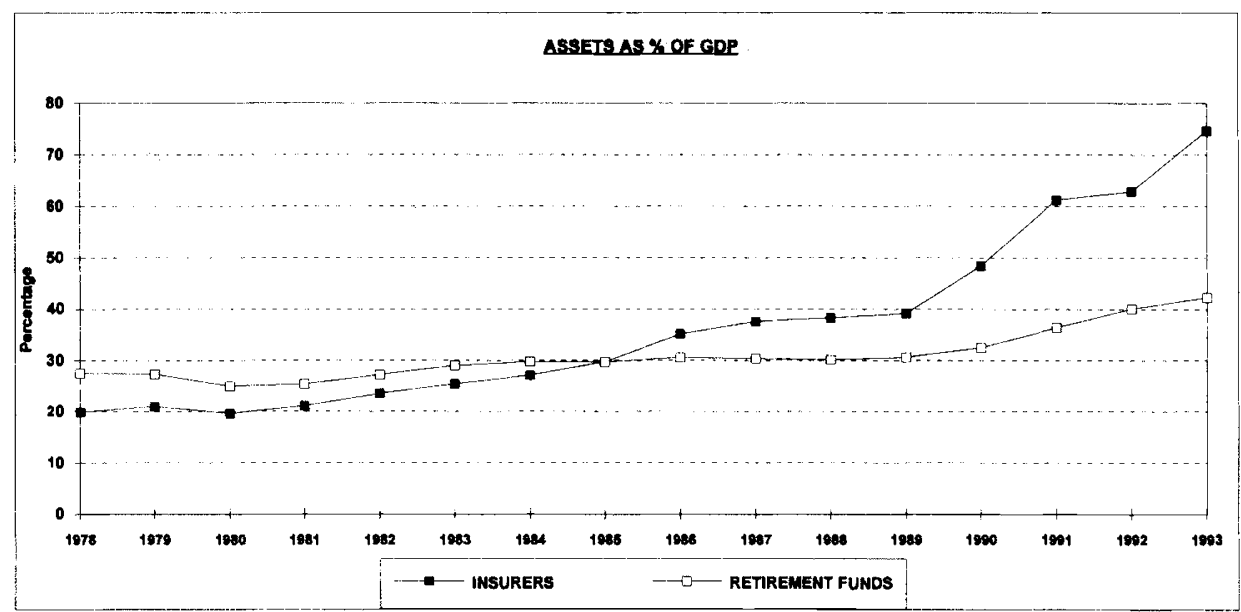

Figure $V$

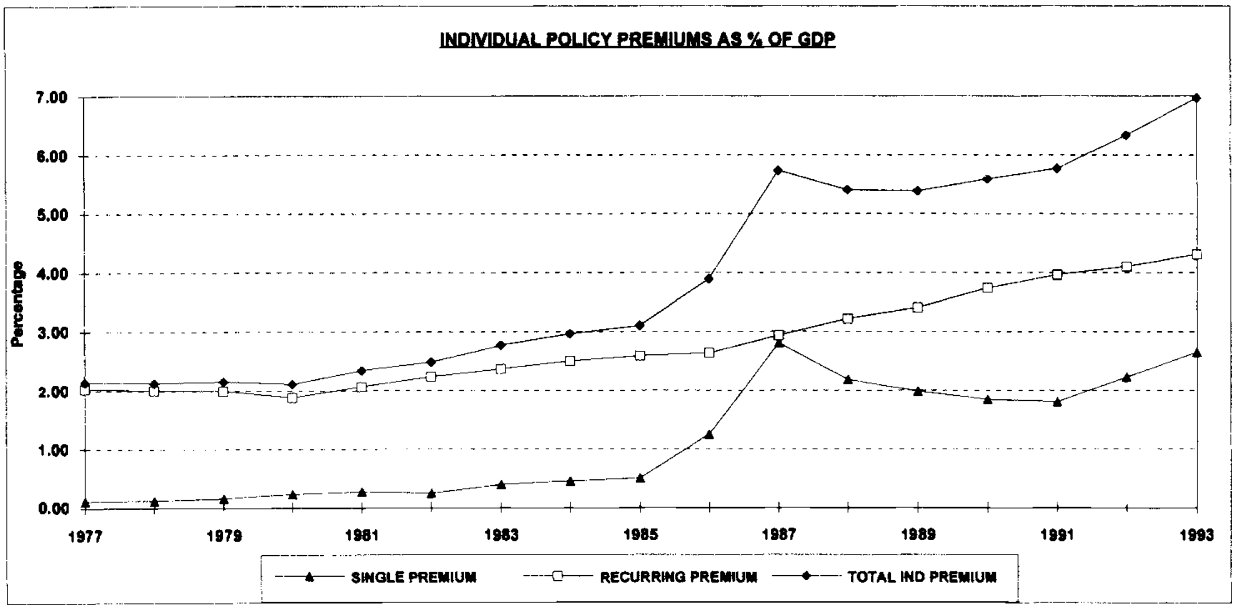

Figure $\mathrm{V}$ indicates that the total recurring premiums on individual policies has doubled from $2 \%$ of GDP to $4 \%$ in 1993.

In 1985 the Minister of Finance announced that the regulations for life insurance were to be amended to prevent perceived unfair competition for deposits by confining life insurers to terms of 10 years or more and preventing life assurers from issuing single premium bonds for shorter terms. Contrary to the Minister's intention, the amendments high- 
lighted that the single premium returns offered by life insurance were better than those given by deposit taking institutions. Life insurers created new products which converted lump sums into annuities which funded annual premium endowments. In addition to the substantial growth in single premiums, the impact of the annual premiums paid into the endowments also contributed to the increasing percentage of GDP in the subsequent years.

Figure VI

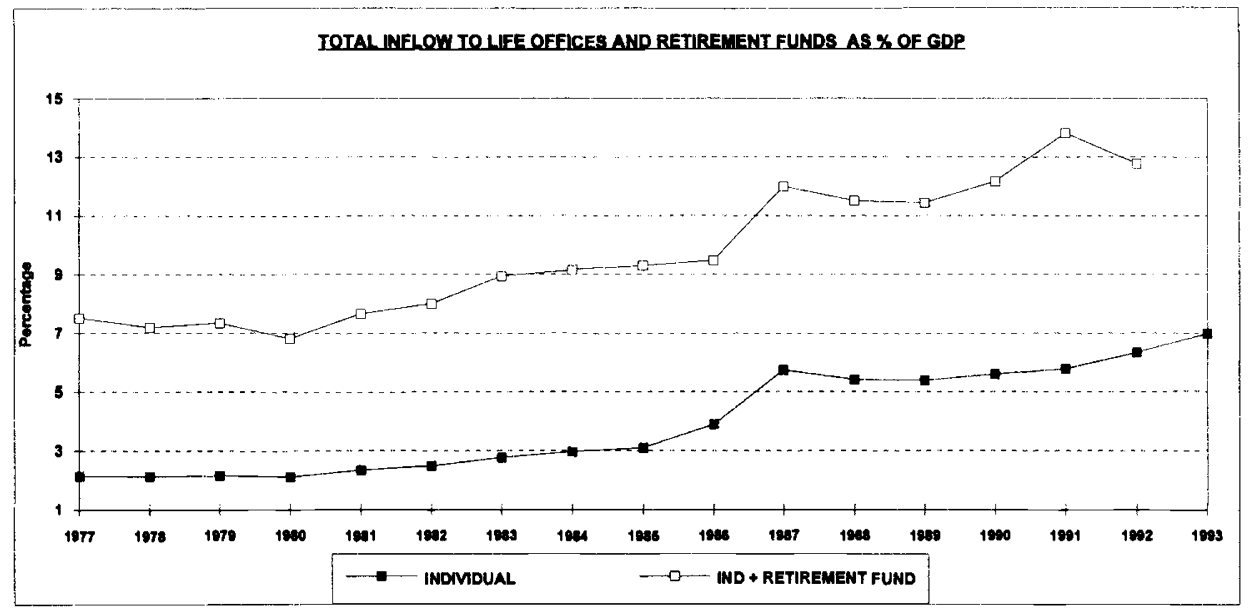

The total inflow to life offices and private retirement funds has increased strongly from $7,5 \%$ of GDP in 1978 to $12,8 \%$ in 1992 , with the life office recurring plus single premium flow increasing from nearly $2 \%$ to $7 \%$ of GDP.

\subsection{Future prospects for life insurance}

The South African economy showed several years of low real growth and negative growth in GDP per capita as the graph below indicates. With South Africa's return to the world the prospects for economic growth have improved. Annual real growth of $2,5 \%$ for 1994 is foreseen and higher growth in following years forecasted. These prospects are positive for both life insurance and retirement provision.

\section{The regulatory environment}

\subsection{Prudential regulation}

The regulatory structure for the conduct of long-term assurance business takes account of the unique nature of the business and is mainly concerned with ensuring financial soundness. The statutory controls include:

a) registration of assurers, and supervision by a statutory Registrar;

b) actuarial supervision and annual investigation; 




c) investment guide-lines and actuarial supervision to ensure that the nature spread of assets is appropriate to the liabilities;

d) control of aspects of marketing including advertising and maximum commissions to agents and independent intermediaries;

e) detailed annual disclosure requirements in returns to the Registrar.

Legal governance of the industry exists largely through four Acts of Parliament. These are the Insurance Act, Pension Funds Act, the Medical Schemes Act, and the Income Tax Act. There are also regulations made under some of these Acts which have the force of law.

\subsection{Marketing Conduct Regulation}

The industry has supplemented these statutory regulatory requirements with strict self-regulation in respect of marketing conduct. The key philosophy behind marketing conduct regulation is that it is focused on complaints rather than compliance with all regulations in every single case. The objective of marketing regulation is to minimise the risk of individual consumer losses occurring as a result of mis-selling, concealment of risks or nondisclosure. Marketing conduct regulation covers such matters as benefit illustrations, advertising standards, disclosure of product provider and marketing firm, a cooling off period enabling the customer to rescind the decision to enter into the transaction, and transparency i.e. the conditions under which any monies or benefits are payable must be clearly disclosed. An ombudsman scheme handles complaints dealing with alleged non-compliance of any marketing principle of regulation. 


\subsection{Taxation of life offices}

In South Africa a "four fund" system of taxation was developed and introduced in March 1993. This approach is based on the so called "trustee principle" which recognises that an insurer essentially holds assets on behalf of its policyholders. Accordingly the tax rate applicable to each fund is determined by reference to the rate applicaple to the underlying policy-owners. There are three policyholders' funds and a corporate fund.

The policyholders' funds are:

- An individual policyholders' fund which is taxed at the average marginal tax rate applicable to individuals (currently $30 \%$ ).

- A company policyholders' fund which is taxed at the company rate (currently $35 \%$ ).

- An untaxed policyholders fund comprising retirement annuity, pension, provident and other benefit fund business and policy contracts with bodies exempt from tax. The rate of tax applicable to this business is zero.

The corporate fund is taxed at the company rate (currently $35 \%$ ).

Normal tax rules apply to taxation of these funds save that any undistributed surplus arising in one or more of the policyholders funds must be transferred to the corporate fund. These transfers generate tax in the corporate fund at the company rate with corresponding tax relief being granted to the policyholders fund at the rate applicable to that fund. It is in fact this transfer of surplus which generates most of the tax under this basis.

\section{Retirement funding}

\subsection{The old age assistance scheme}

The state old age assistance scheme is funded from general revenues and pays a flat pension to all aged people, subject to a means test. The qualifying age is 65 years for men and 60 years for women. The pension amount has been increased each year to give some protection against inflation. Each spouse in a married couple can receive the maximum amount, subject to the means test. Currently (1994) the flat pension amounts to 375 rand (\$100) a month.

The budgetary cost of old age pensions is only just over $1 \%$ of GDP. This relatively low cost is explained by the very young demographic structure of South Africa and by the use of the means test. Of a total retired population of 1,9 million people, 1,1 million (or $2,8 \%$ of the total population) rely on the state old age assistance scheme.

\subsection{Occupational retirement fund schemes}

Because of the limited scope of the old age assistance scheme, especially for middle and high income workers, South Africa has experienced a proliferation of occupational retirement fund schemes. These are either company based covering employees of particular companies or industry wide schemes covering employees working in particular industries. The latter are often the result of collective agreements with trade unions and are supervised by the Department of Manpower. 
There are two types of occupational retirement schemes: provident funds, which provide a lump sum on retirement (benefits are mostly accumulated contributions and investment income, though there are also provident funds that provide benefits that depend on final salaries and/or years of service); and pension funds, which pay a monthly pension that is normally based on a percentage of pensionable salary for each year of service (though pension funds may also operate as defined contribution plans). One third of the value from pension funds may be commuted into a lump sum at retirement. Provident funds have traditionally been established for workers where income is irregular or may decrease before retirement.

In 1991 there were over 15000 occupational retirement schemes in South Africa. The vast majority, over 13800 , were underwritten by insurance companies while about 1300 were self-administered, 19 were industrial funds and 18 were state-controlled as official funds. Total membership amounted to 9.8 million, of which almost 1 million were pensioners and the rest were active workers. Total membership is exaggerated by double counting as many workers are members of more than one fund. A recent government investigation into retirement provision applied a correction and estimated the total number of active workers covered by occupational pension schemes at probably 6,5 million people which is about $70 \%$ of the formally employed labour force.

\subsection{Benefit trends}

The growth of influence of the trade union movement in South Africa has led to retirement fund benefits taking on a new direction. This represents a shift of emphasis away from saving for old age, towards meeting "life crises", such as death, unemployment, disablement and providing finance for housing. The emphasis on benefits payable before retirement has therefore increased.

Benefits on voluntary resignation are being increased through both higher interest rates payable on withdrawal and by allocating a portion of the employer's benefit contributions. Unions have also supported funds covering blue collar workers being in the form of provident funds, thereby paying a lump sum instead of a pension when the member reaches normal retirement age.

There is a greater emphasis on the negotiation of pension benefits between employees and employers as part of the overall remuneration package, instead of large employer determination as addition to wages. There is some pressure for representation by unions at trustee level. This included having a say in the investment policy of the fund. Employees are requesting that their pension entitlements be made available as loans for education and housing purposes. They are also asking for lower contribution rates to apply in the case of individual needy employees.

\section{Health insurance}

Traditionally health insurance has been an important fringe benefit offered by employers in South Africa. Health insurance cover is generally available to all who are in full employment where both the employer and the employee jointly contribute to a scheme. Medical aid schemes are the most common type of scheme, followed by Exempt schemes and Benefit schemes. Exempt schemes are schemes which are exempted from 
complying with the provisions of the Medical Schemes Act and Benefit schemes operate on a panel system where members have a limited choice of doctor. Approximately $30 \%$ of the total population are covered by such schemes with the remainder relying on the state.

The persistent rise in health care costs through the 1980's as a result of rapidly rising medical costs and rampant claims experience has seriously undermined the viability of the current system of health cover. Health care expenses have become a major business cost and traditional employer-sponsored schemes have fast become unaffordable. It is within this environment that amendments to the Medical Schemes Act were conceived and subsequently passed by Parliament to become effective from January 1994. The changes to the Medical Schemes Act provided for, the abolition of the statutory Scales of Benefits, guaranteed direct payment and imposed minimum and maximum benefits. The distinction between medical aid and medical benefit schemes was abolished, allowing medical schemes to enter the supply side of the market on a wide basis.

The immediate result has been that the market has seen a proliferation of product offerings taking advantage of the changes. The Representative Association of Medical Schemes (RAMS) tariff guide, which previously defined the minimum and maximum benefits payable to suppliers by medical aids, is now merely a guide to fees charged by suppliers of services. Most medical aids, still reimburse providers based on this guide.

\section{Managed care}

Recently, there has been a move away from a fee-for-service system towards managed care. In a fee-for-service system scheme members generally have free choice as to provider, while the latter effectively control both price and utilisation. Neither patient or provider are given much incentive to question the cost, the appropriateness of or effectiveness of the care provided. In this system employers can limit their share of costs by shifting them to employees, but they cannot control the total costs, utilisation or price. A Managed Care System on the other hand seeks to contain total costs over time by reducing utilisation, and price through a more controlled and integrated health care purchasing and delivery system, consisting of a network of pre-qualified local providers who share information and practice medicine according to predetermined clinical standards. Primary care physicians co-ordinate care for each covered individual while a network manager (typically the insurance carrier) supervises the clinical, financial, and administrative aspects of the network's operation. Incentives for providers and patients are build into the system and utilisation and quality are carefully monitored.

Life offices currently offer health insurance as a form of "top-up" to the limited benefits that a medical aid pays in the event of major surgery and hospitalisation. As most of these products provide cover for the lifetime of the insured, funds are accumulated in advance so that the high cost of post-retirement medical care becomes affordable. The trend is for these health insurance policies to be incorporated with a medical aid scheme to provide individuals with comprehensive medical insurance cover.

\section{Individual business}

Traditionally life assurance companies have been selling policies to individuals in the following three main categories, life, endowment and retirement annuity products. 
Recently legislative changes have made it possible to sell policies with a five year term whereas previously they were restricted to 10 years. The requirement that life cover had to be built into products has also been removed. The market response to the new shorter term investment products has been enormous and this development has accelerated a growing trend over the past 20 years for the term of life policies to get shorter as people's time horizons contracted dramatically and inflationary expectations took hold of investment planning. The swing has been away from predominantly risk products to predominantly investment products. This trend has been fuelled by retirement schemes providing substantial group life cover, enabling people to opt for investment products.

\section{Dread disease products}

The South African life industry pioneered the so called "dread disease" policies. There are now over ten "dread diseases" including full blown AIDS covered under a dread disease benefit. The number of diseases covered is low compared with the policies sold in the UK; in South Africa these extra diseases are covered in the health insurance Major Medical Expense products.

\section{Reinstatement of life cover}

Another innovation in the South African market has been the emergence of reinstatement of life cover options being made available on policies that have a disability or dread disease benefit attached. These options allow for the life cover to be reinstated following a disability or dread disease claim by the amount of the claim. The life assured has to submit a negative HIV test and survive a 90 day waiting period for the life cover to be effective.

\section{Aids}

With applicants for life assurance being tested HIV positive in $10 \%$ of the cases in some regions in South Africa, the AIDS epidemic is becoming a real threat to the South African life assurance industry. The industry's response has been to request HIV tests; where tests are not selected an exclusion clause applies. In all cases the mortality rates have included an appropriate loading for the expected increase in risk.

An innovation by a few life offices is that of requiring repeat HIV tests every five years up to the age of 45 or 50. Following a positive HIV test the policy is converted to a pure endowment or the cover is reduced linearly to zero over 5 years. This has allowed premium rates to remain very competitive as all AIDS loadings are removed. Mortality charges are also guaranteed not to increase as a result of AIDS mortality.

\section{Equity linked annuities}

Another development which has proved itself a driving force in the industry was the introduction of unit trust-linked annuities. The product gave investors the ability to participate with more flexibility, in unit trust portfolios, some of which have historically outperformed the life industry's portfolios.

The product has dealt with many apparent weaknesses of the conventional fixed life annuities. At inception and at least every year the investor can select a portfolio of unit 
trusts into which annuity capital is invested while retaining the right to switch portfolios between unit trusts offered by the fund. The need to choose between a single or joint life annuity was removed and a nominated beneficiary automatically inherits the capital in the "annuity" fund at the time of death of the annuitant. Decisions can be made on a year-toyear basis, or more often if required, on the minimum or maximum level of monthly income (annuity) drawn to suit prevailing financial circumstances.

There are drawbacks for these "annuities". The annuitant can have his/her "annuity" capital exhausted should they outlive their capital. As the income is drawn from a fund growing in line with the performance of the unit trusts, any income drawn that is greater than the growth of the fund could cause the fund to run down to zero if the annuitant lives too long or alternatively the annuitant may need to take a much lower income. The risks of a fall in the stock market can also eliminate a large portion of an annuitant's retirement capital so these annuities are generally aimed at the more sophisticated end of the market.

\section{Comparative investment returns}

A key contributor to the success that Life Offices have had in attracting money has been the broadly held perception that an investment in a life policy is better than investing in a bank deposit.

Table II below demonstrates the investment mix adopted by Life Offices together with the returns that would have been obtained had they invested in the Johannesburg Stock Exchange Indices.

Table II:

Investment strategy and comparative returns Life offices' asset distribution

Rmil

\begin{tabular}{|c|c|c|c|c|c|c|c|c|c|c|c|c|}
\hline & 1978 & $\%$ & $\begin{array}{c}5 y r \\
\text { Ave } \\
\text { Return } \\
\%\end{array}$ & 1983 & $\%$ & $\begin{array}{c}5 y r \\
\text { Ave } \\
\text { Return } \\
\%\end{array}$ & 1988 & $\%$ & $\begin{array}{c}5 y r \\
\text { Ave } \\
\text { Return } \\
\%\end{array}$ & 1993 & $\%$ & $\begin{array}{c}5 \mathrm{yr} \\
\text { Ave } \\
\text { Return } \\
\%\end{array}$ \\
\hline 1. Fixed Interest & 3033 & 41 & 10.2 & 9804 & 42 & 6.2 & 34058 & 41 & 14.2 & 78967 & 28 & 22,3 \\
\hline 1.1 Cash & & & 9.9 & & & 11.4 & & & 15.4 & & & 17,3 \\
\hline 2. Equities & 1463 & 20 & 11.8 & 6127 & 26 & 34.0 & 31386 & 38 & 21.6 & 147337 & 53 & 24,0 \\
\hline 3. Fixed Property & 1203 & 16 & 3.0 & 4232 & 18 & 39.6 & 11241 & 13 & 10.8 & 28451 & 10 & 19,4 \\
\hline 4. Misc. (Loans) & 1713 & 23 & - & 3223 & 14 & - & 6570 & 8 & - & 23352 & 9 & - \\
\hline Total Assets & $\begin{array}{c}7412 \\
(1)\end{array}$ & 100 & (2) & $\begin{array}{c}23386 \\
\text { (1) }\end{array}$ & 100 & (2) & 83255 & 100 & (2) & $\begin{array}{c}278106 \\
\text { (1) }\end{array}$ & 100 & (2) \\
\hline
\end{tabular}

(1) Life Offices Association

(2) Johannesburg Stock Exchange Index 
Table II shows that equities have been the preferred asset channel for life offices. The equities stake in the total portfolio has constantly been increasing for the last fifteen years and amounted to some $53 \%$ at end December 1993 . This strategy has been clearly vindicated by the annuallised returns. Since 1983 the relative exposure to property in the total portfolio has been declining. The dramatic shift from fixed interest to equities that occurred between 1988 to end 1993 followed the removal of the requirement, that had existed for many years, to invest a substantial proportion of assets in "prescribed assets" which were largely government and quasi-government bonds.

Table III below shows the kind of returns that have been available on non life insurance investments. Unit Trusts (Mutual Funds) have also enjoyed success over this period with the 1978 to 1993 total amount invested moving from $0,9 \%$ to $2,9 \%$ of GDP.

Table III:

Johannesburg Stock Exchange returns for the 5 years to December

\begin{tabular}{|l|c|c|c|c|}
\cline { 2 - 5 } \multicolumn{1}{c|}{} & 1978 & 1983 & 1988 & 1993 \\
\hline 6 Months Fixed Deposits & 10.1 & 11.5 & 15.9 & 18.8 \\
12 Months Fixed Deposits & 11.2 & 13.1 & 17.5 & 19.1 \\
\hline
\end{tabular}

A comparison of the two tables clearly demonstrates that over the 20 years considered investors in Life Insurance investment products have been likely to have obtained a better return, even after tax on life insurers and expense deductions, than investors in the other vehicles considered.

Clearly the future success of Life Insurance in South Africa will be dependent on this trend being maintained.

\section{Impact on economic development}

While South Africa has suffered as a result of the isolation years during Apartheid, it continues to be the African continent's most successful economy. As the country looks towards reconstruction and development the life assurance industry will continue to play a central role:

- As a source of development capital: By investing in the shares of limited companies the life assurers help to create jobs by providing capital for companies to expand their operations.

- As a driving force behind development of the country's infrastructure: By investing in government stock life assurers help to provide capital for the development of the infrastructure to support economic expansion.

- As job creator through the funding of business ventures and as a developer of commercial and retail property. 
Primarily, the industry puts contractual savings to work. In South Africa, this takes on an added dimension, given a vast reduction in discretionary savings over the past decade. The profits derived from investment of this saving flow go towards enhancing the claims paid to policyholders. The recipients of these claims may be widows, orphans, pensioners, disabled and sick people requiring medical treatment.

In addition to this traditional role, the industry is increasingly playing a part in major development projects, most notably through the establishment of an Investment Development Unit (IDU). It was created in the first half of 1993 by the Life Offices' Association (LOA) with the brief to identify and develop investment opportunities that marry the needs of policyholders with the need to mobilise these savings for the overall benefit of the country. Recently one billion rand ( 0,28 billion dollar) was allocated to the electrification of low income households, while investment in low cost housing is next on the agenda.

\section{REFERENCES}

Vittas, D. Policy Issues in Contractual Savings in South Africa. June 1994.

Mouton Committee. Report of the Committee into a Retirement Provision System for South Africa, November 1992.

The International Group Program Country Profile on South Africa. Old Mutual report (July 1994).

Clegg, D. Life Assurance Taxation. Tax Planning. Vol 7, 1993.

World Insurance in 1992. Sigma Economic Studies. Swiss - SA Re. March 1994. 